\title{
Field Measurement for Investigating the Dynamics of Currumbin Creek Tidal Inlet Entrance
}

\author{
Saeed Shaeri $\uparrow$, Rodger B. Tomlinson $\dagger$, Amir Etemad-Shahidi $\uparrow$, Darrell Strauss $\dagger$, Shannon Hunt $\infty$ \\ $\uparrow$ Griffith Centre for Coastal \\ Management, Griffith University, Gold \\ Coast Campus, QLD 4222, Australia \\ saeed.shaeri@griffithuni.edu.au \\ r.tomlinson@griffith.edu.au \\ I School of Civil Engineering, Griffith \\ University, Gold Coast Campus, QLD \\ 4222, Australia \\ a.etemadshahidi@griffith.edu.au \\ $\infty$ Engineering Services, Gold Coast \\ City Council, Gold Coast, QLD 9729, \\ Australia \\ shunt@goldcoast.qld.gov.au
}

d.strauss@griffith.edu.au

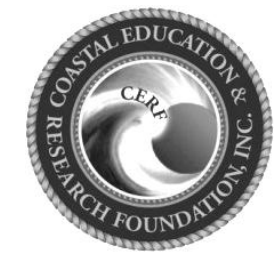

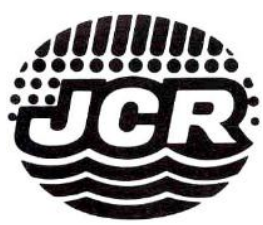

www.JCRonline.org

\section{ABSTRACT}

Shaeri, S., Tomlinson, R.B., Etemad-Shahidi, A., Strauss, D. and Hunt, S., 2013. Field measurement for investigating the dynamics of Currumbin Creek entrances In: Conley, D.C., Masselink, G., Russell, P.E. and O'Hare, T.J. (eds.), Proceedings 12th International Coastal Symposium (Plymouth, England), Journal of Coastal Research, Special Issue No. 65, pp. 1212-1217, ISSN 0749-0208.

\begin{abstract}
Currumbin Creek is a small tidal inlet in south-eastern Queensland, Australia. There is a long history of morphological changes, entrance stabilization works and maintenance dredging activities. Despite these activities an effective longterm management plan is yet to be implemented. A key component of the development of such a plan is a model of morphological change, and this paper addresses an investigation of the dynamics of the whole system. A field campaign carried out in March, 2011 and included measurement of nearshore wave regimes, tidal levels and currents inside the creek, and also drogue tracking in the inlet entrance. Wave data was collected over six weeks by ADCPs in water depth of about 7-8 $\mathrm{m}$. Tidal current discharges were also measured by an ADCP over two tidal cycles of 14.4 (spring) and 15 (neap) hours. Water levels were recorded using a Valeport Water Level Recorder during the whole measuring period. The investigations show that the creek is mixed, but mostly flood dominated and therefore, there is a reasonable potential for sediment to rapidly infill the entrance and for the entrance to be dominated by natural bypassing. This study is part of a broader research project aiming to maintain longer, more durable and stable tidal-inlet entrance channels in Currumbin Creek. These findings will contribute to the design of alternative entrance geometry or maintenance strategies in the next phase.
\end{abstract}

ADDITIONAL INDEX WORDS: Tidal discharge, tidal level, tidal prism, tidal velocity, tidal constituents, drogue tracking.

\section{INTRODUCTION}

Tidal inlets are one of the most valuable geographical features on our coastlines. Periodic exchange of water from the ocean through an inlet and to its back-barrier not only provides fresh nutrients for flora and fauna, but also provides navigation to upstream riverside shores. However, in small tidal inlets, the entrance seldom has enough water depth to provide safe navigation all year round (Castelle et al., 2007, D'Agata and Mc Grath, 2002). In addition, there is always a high risk of rainfall inundation as the entrance lacks sufficient capacity to convey the excess runoff resulting from heavy rainfall into the ocean (Maritime Safety Queensland, 2011). Although the easiest way to mitigate this risk is to periodically dredge the entrance, in most cases dredging is not considered financially viable. Moreover, there is considerable historical evidence that such dredging can result in excessive erosion of the downdrift beach. This study presents comprehensive field measurements to investigate the dynamics for Currumbin Creek tidal inlet entrance and it is a part of a larger project dealing with a morphological study of the area.

\section{STUDY AREA}

The study area is situated in south-eastern Queensland, Gold

DOI: 10.2112/SI65-205.1 received 07 December 2012; accepted 06 March 2013.

(c) Coastal Education \& Research Foundation 2013
Coast City, Australia. There are a number of tidal inlets in this area, which have been investigated over a long period of time (D'Agata, and Tomlinson, 2001). However, the extent of this study focuses only on Currumbin Creek (highlighted in Figure 1).

\section{FIELD SURVEYS}

An extensive field measurement campaign was conducted for the Gold Coast City Council by the DHI Group and the Griffith Centre for Coastal Management (GCCM) in March and April, 2011. The field campaign included measurements of:

- nearshore wave/current regime at five different locations

- creek current discharges

- creek water level variations

- drogue tracking around the creek inlet entrance

Wave data was collected by RDI-ADCPs (deployed at a depth of about $7.5 \mathrm{~m}$ ) from April $12^{\text {th }} 2011$ until May $30^{\text {th }} 2011$, with a one-week gap for data acquisition. In the following sections, the two stages of the data collection period are referred to as the first and second halves.

Similarly, tidal discharges were measured on the $6^{\text {th }}$ and $12^{\text {th }}$ of May, 2011. These data were collected by a boat-mounted RDIADCP transecting across an arbitrary cross-section of the creek width at half-hour intervals. An aerial view of the in-situ instrument stations is presented in Figure 2.

Water levels were also recorded using a Valeport Water Level 


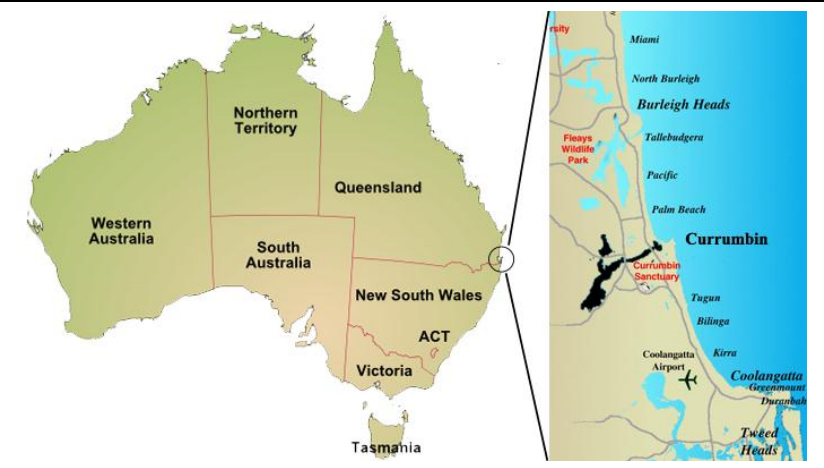

Figure 1. Study Area Map, Currumbin Creek

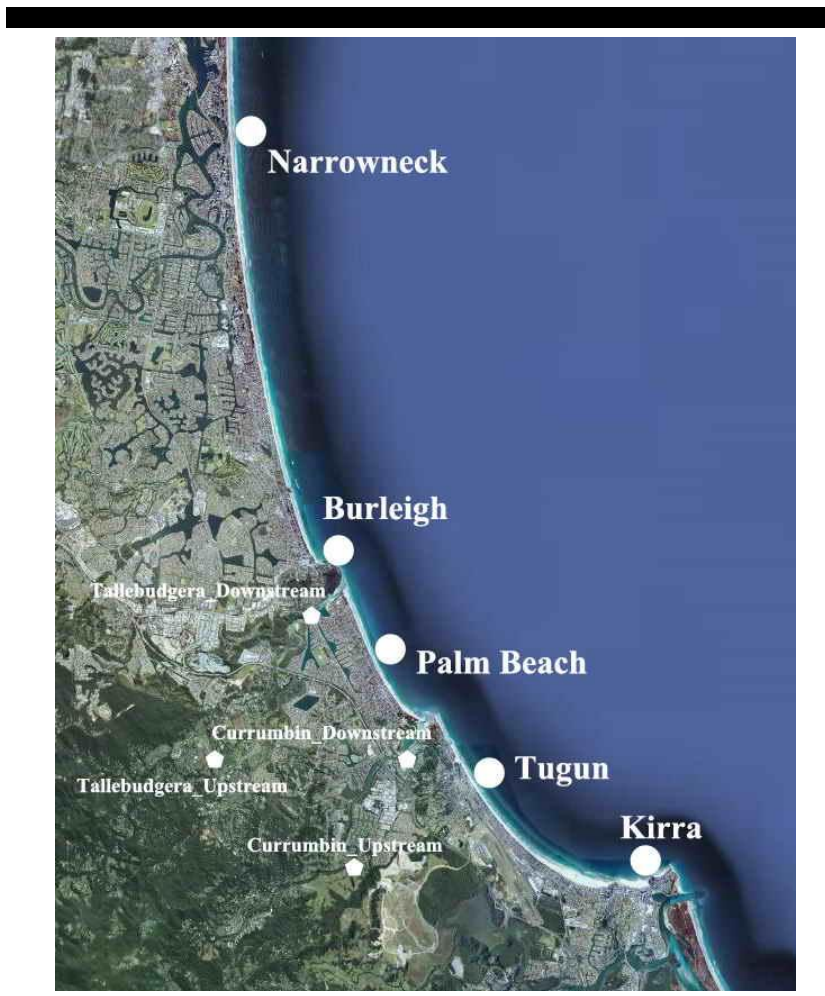

Figure 2. Aerial view of the data collection stations

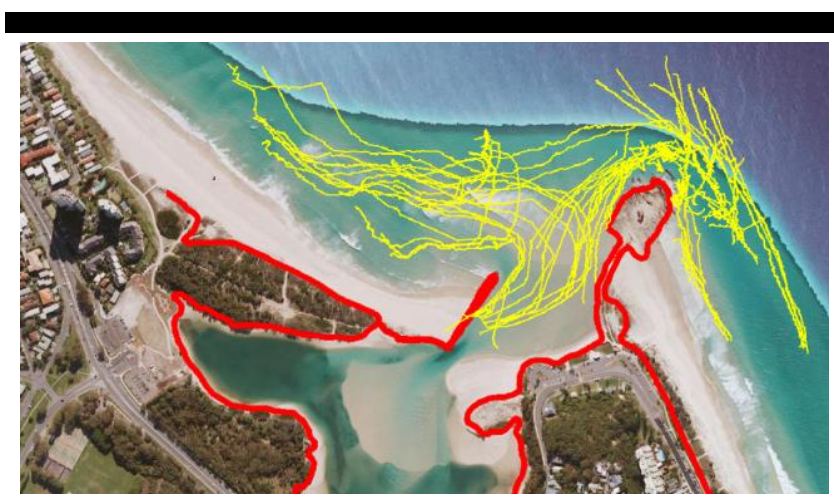

Figure 3. Drogue tracks

Recorder from April 14 2011 and retrieved on May $30^{\text {th }} 2011$, with a few days gap for maintenance in-between. Furthermore, to understand the general patterns of the longshore and tidal currents,
Table 1. Wave characteristics for adjacent stations.

\begin{tabular}{|c|c|c|c|c|c|}
\hline \multirow[t]{2}{*}{ Stations } & \multicolumn{2}{|c|}{ 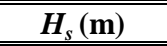 } & \multirow{2}{*}{$\underset{(m)}{\operatorname{Hmax}}$} & \multirow{2}{*}{$\begin{array}{c}\text { Tpeak } \\
(s)\end{array}$} & \multirow{2}{*}{$\begin{array}{l}\text { Dir. } \\
\text { (deg) }\end{array}$} \\
\hline & $\operatorname{Max}$ & Min & & & \\
\hline \multicolumn{6}{|c|}{ First Half of measurement } \\
\hline Tugun & 2.02 & 1.03 & 2.56 & $4.50-14.90$ & $40-110$ \\
\hline $\begin{array}{l}\text { Palm } \\
\text { Beach }\end{array}$ & 1.98 & 1.10 & 2.51 & $4.50-14.90$ & $40-130$ \\
\hline \multicolumn{6}{|c|}{ Second Half of measurement } \\
\hline Tugun & 1.81 & 0.89 & 2.30 & $6.02-19.50$ & $30-120$ \\
\hline $\begin{array}{l}\text { Palm } \\
\text { Beach }\end{array}$ & 1.99 & 0.88 & 2.53 & $6.20-19.50$ & $\begin{array}{l}\text { Missing } \\
\text { Data }\end{array}$ \\
\hline
\end{tabular}

Table 2. Current characteristics of adjacent stations.

\begin{tabular}{lll}
\hline Stations & \multicolumn{1}{c}{$\begin{array}{c}\text { Maximum Current } \\
\text { Speed }(\boldsymbol{m} / \mathbf{s})\end{array}$} & $\begin{array}{c}\text { Dominant direction } \\
(\mathbf{d e g})\end{array}$ \\
\hline First Half of measurement & \\
\hline Tugun & 0.49 & $315(\mathrm{NW})$ \\
Palm & 0.32 & $337.5(\mathrm{NNW})$ \\
Beach & \\
\hline Second Half of measurement & \\
\hline Tugun & 0.26 & $337.5(\mathrm{NNW})$ \\
Palm & Missing Data & Missing Data \\
Beach & & \\
\hline
\end{tabular}

a drogue tracking exercise was conducted on the $18^{\text {th }}, 25^{\text {th }}$ and $27^{\text {th }}$ of May, 2011. Overlay maps of all drogue trajectories are shown in Figure 3.

\section{RESULTS AND DISCUSSION}

\section{Nearshore Wave and Current Measurements}

Although wave and current measurements were obtained from five different stations along Gold Coast's beaches (Figure 2), only the results of the two stations adjacent to the creek (that is Palm Beach and Tugun) are discussed here. The wave and current characteristics for these stations are presented in Tables 1 and 2. A series of wave and current roses are also presented in Figures 4 and 5. Pressures recorded by the ADCPs were used to provide depth measurements at each station. The resulting water level variations are discussed separately in the 'Tidal Analysis' section.

Comparing the aerial map (Figure 2) of the beaches with the wave roses (Figure 4), it could be inferred that these different stations recorded approximately the same nearshore wave climate. In other words, the curvature of the beach (around the northern side of the creek) makes no particular change to the nearshore wave direction and the waves approach approximately from the NE (Vila-Concejo et al., 2007). This is also the case for the peak wave period (Table 1) as the figures are very similar to each other in terms of highs and lows. However, as expected, due to the width of the continental shelf and the slope of the beach, there are reasonable differences between the (significant or maximum) wave heights measured at different stations.

As mentioned before, there are also recorded depth-averaged current data for each station. Figure 5 shows their corresponding current roses. The maximum current speed and the dominant direction (derived from current roses) are presented separately in Table 2. ENE is the dominant direction of the incoming waves during the measurement periods, however the current roses show that the current directions do not strictly follow the wave induced directions and currents are recorded in all directions. This could be attributed to two possible reasons. The most pivotal effect is due to tidal currents which make the current distribution different to that of the waves. Hence, the water level measurements need to be 
Stations
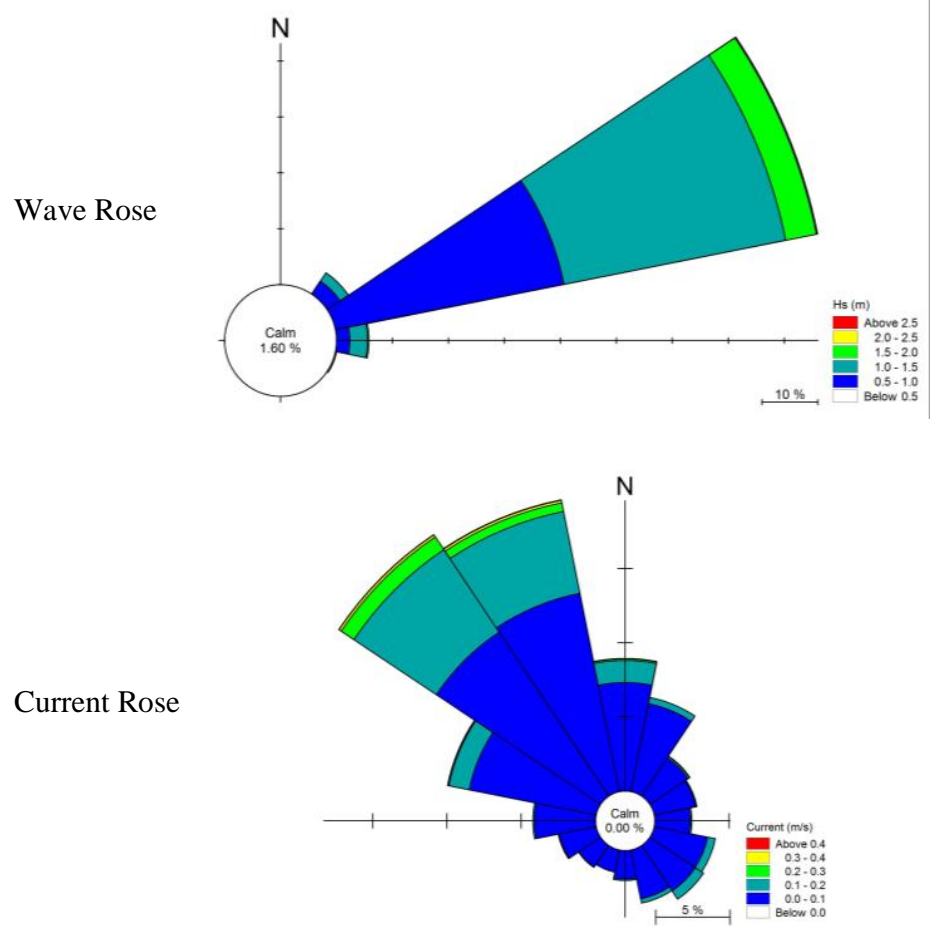

Second Half
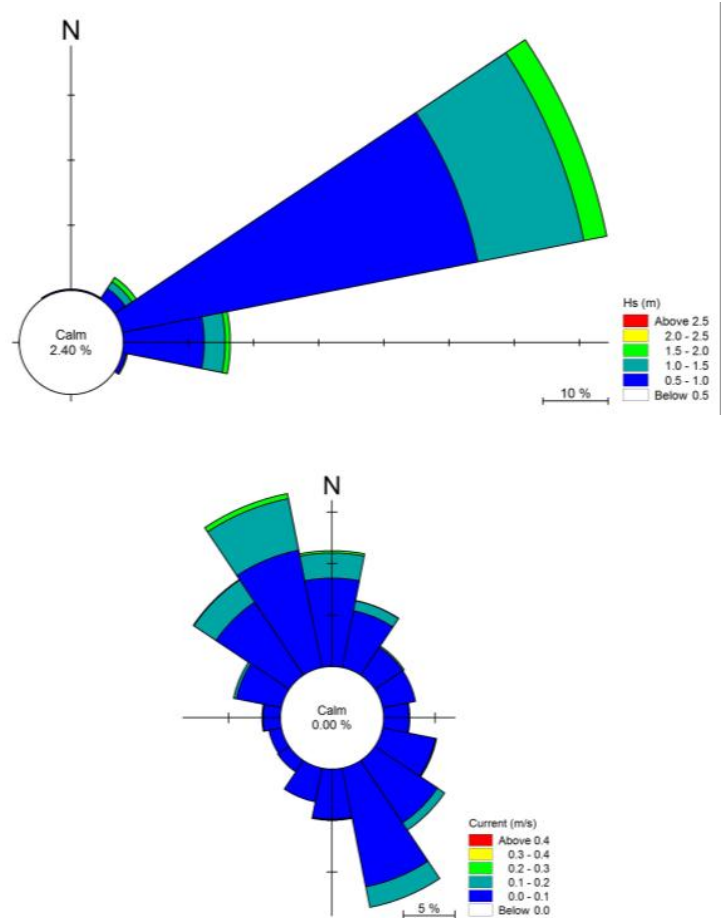

Figure 4. Wave and Current roses for Tugun station

analyzed in more detail (see the 'Tidal Analysis' section). The second reason could be related to the effect of the East Australian Current (EAC) which flows North to South from the Coral Sea and thus may correspond to the NW-NNW sectors of the current roses. Detailed analysis of the EAC interactions with shallow coastal waters is not in the scope of this study and needs to be addressed in another study.

\section{Tidal Level inside the Creek}

The tidal variations of water levels inside the creek were measured at two separate stations. The first station was located close to the entrance and the other was about $4 \mathrm{~km}$ upstream from the entrance. By visualizing water levels during the measured periods, it was concluded that the upstream station is not largely influenced by the creek's geometry and most of the upstream tidal dynamic parameters are roughly the same as the downstream ones (Figures 6 and 7). The details are as below:

- On average, the tidal range is about $1.1 \mathrm{~m}$.

- The average difference between the highest upstream water level and highest downstream water level stations is about $8 \mathrm{~cm}$. Correspondingly, the highest upstream water level happens about 20 minutes after the downstream event (time lag). This means that the average speed of the tidal wave propagation is about $3.4 \mathrm{~m} / \mathrm{s}$.

- The average difference between the lowest upstream and downstream water levels is about $5 \mathrm{~cm}$. Likewise; the lowest upstream water level occurs 19 minutes after the downstream one, leading to a $3.6 \mathrm{~m} / \mathrm{s}$ propagation speed. A similar propagation speed for flood and ebb waves indicates that tidal changes are almost symmetrical.

- The time difference between a low-water and the previous high-water event (ebb time duration) is 6:43 hrs for the upstream station and 6:40 hrs for the downstream station. As this approximately equals $6.25 \mathrm{hrs}$, the tide can be considered predominantly semi-diurnal. Alternatively, the flood time duration is $5: 43(5: 46)$ hrs for the upstream (downstream) station. Consequently, the duration of the average semi-diurnal tidal cycle is about 12:42 hrs.

- Although the average flood and ebb propagation speeds are identical, noting that the ebb time duration is longer than the flood duration reveals that the creek is flood dominated.

\section{Tidal Discharge from the Creek}

Tidal discharge measurements have been conducted by means of a boat-mounted ADCP. This operation was performed on two different days (for about 15 hours each). The water flux was measured in small vertical columns of the cross-section and recorded as one transect, by moving very slowly from one bank to the opposite one and recording current velocity profiles. Then, by integrating those measurements (fluxes), total water discharge was calculated for each transect. Based on temporal changes of flow fluxes during a 15-hour period, the current speed and tidal flow durations were inferred from the graphs (Figures 8 and 9) (Hoque et al., 2010). In these figures, positive signs denote an ebb tide current from the creek towards the ocean; and negative signs show flood tide currents.

The area between the measurement curve and the horizontal (time) axis defines the amount of water exchanged during a flood/ebb period (the amount of tidal prism). Table 3 shows a summary of these results. Larger water discharges and velocities during a flood event (Figure 8) are indicative of flood dominance on the first day of measurement, while Figure 9 shows a symmetric pattern.

Table 3 shows the calculated tidal prisms. As seen, as the flood 
Stations

\section{Current Rose}

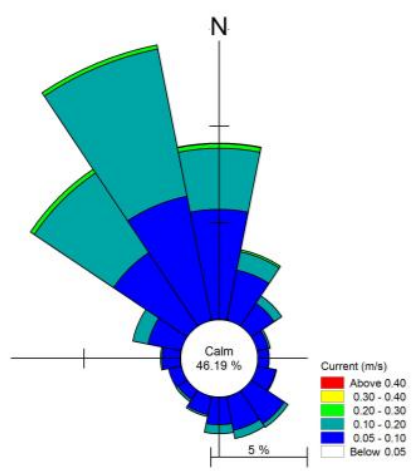

Wave Rose

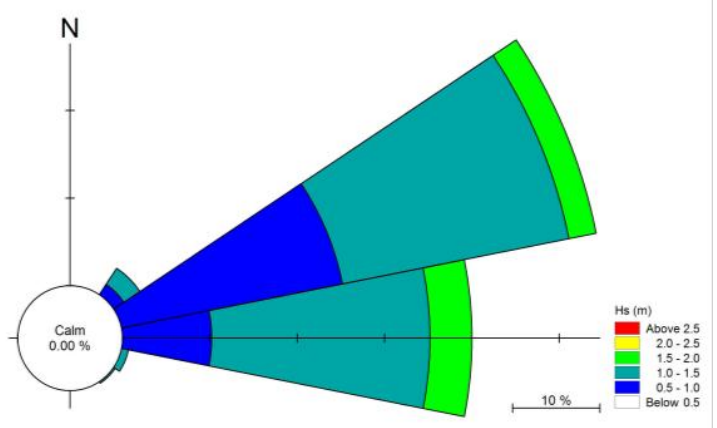

Figure 5. Wave and Current roses for Palm Beach station (Available data for the first half of the deployment)

Table 3. Flood/Ebb durations and Tidal Prisms

\begin{tabular}{lccc}
\hline \hline & $\begin{array}{c}\text { Tide Duration } \\
(\boldsymbol{h r s})\end{array}$ & $\begin{array}{c}\text { Tidal Prism } \\
\left(\boldsymbol{m}^{\mathbf{3}}\right)\end{array}$ & Prism Type \\
\hline Day 1 & $04: 59$ & 420,600 & Ebb \\
& $06: 36$ & $1,177,200$ & Flood \\
\hline Day 2 & $06: 28$ & 962,450 & Flood \\
& $06: 05$ & 780,550 & Ebb \\
\hline Average & & 835,200 & \\
\hline
\end{tabular}

Table 4. Flow speed at an arbitrary cross-section of the creek

\begin{tabular}{lccc}
\hline & Max. & Average & Min. \\
\hline Day 1 & 0.17 & -0.06 & -0.36 \\
\hline Day 2 & 0.28 & 0.01 & -0.28 \\
\hline
\end{tabular}

prisms are larger than the ebb prisms, it can be concluded that the creek is flood dominated. However, slight differences between flood and ebb tidal durations indicate that they may not always be flood dominated. This emphasizes that the dominance of a tidal regime could not be inferred from the limited data and that long term data are essential to determine the creek's tidal regime.

The extreme flow velocities of Figure 9 are presented in Table 4. Here again, positive numbers show ebb current and negative values indicate flood current. It can be seen that the absolute value of minimum flow velocities are more than maximum ones. This means in all circumstances, the tidal flow is flood dominated. This is also evident from the negative sign of average current speeds.

\section{Tidal Analysis}

With the tidal water level data, it is possible to perform a tidal constituent analysis. The results of such an analysis are presented in Table 5. In this table, the first two rows of data are from both the upstream and downstream stations of the creek respectively (see the 'Tidal Level inside the Creek' section). The other two rows display the variations of water depth which were recorded by the ADCP (the 'Nearshore Wave and Current Measurements' section) at the Palm Beach station. As discussed earlier, it is assumed that these quantities are mostly tidally driven.

In Table $5, \mathrm{Z}_{0}$ is regarded as the average water level data for constituent analysis and $\mathrm{M}_{2}, \mathrm{~S}_{2}, \mathrm{~K}_{1}$ and $\mathrm{O}_{1}$ are four major tidal constituents, which are derived from the harmonic analysis of the data. In addition, the last column shows the well-known ratio of amplitudes of $\left(\mathrm{K}_{1}+\mathrm{O}_{1}\right) /\left(\mathrm{M}_{2}+\mathrm{S}_{2}\right)$, which indicates the type of tidal variations. Here, because all ratio numbers are between 0.25 and 1.5, they indicate a mixed, but mostly semi-diurnal tide type, which is also in accordance with the results obtained from the 'Tidal Level inside the Creek' section.

Table 5 shows there is no significant differences between the creek's upstream and downstream stations, the amplitudes of the major tidal constituents are about the same and the net effects of friction and amplification are considered negligible in this water body.

In addition, it is seen from the last two rows of Table 5 that the offshore station has resulted in similar figures for both half periods. It is also evident that the creek quantities are similar to the offshore stations and this indicates a good conformity to tidal currents in this inlet.

\section{Drogue Tracking}

Drogue tracking is a very powerful tool (Hughes, 2002) to identify flow patterns in complicated situations, like tidal entrances. In this study, drogue measurements were designed in a way to be performed on both flood and ebb tides. Drogues were released in locations which were considered to be good representatives of normal flood/ebb currents and their trajectories were recorded by conventional handheld GPSs (Figure 3).

Table 6 and Figure 10 show the longest and shortest drogue paths with their representative drogue IDs. Moreover, the minimum and maximum elapsed times between drogue release and collection are presented in this table as well. Based on the individual displacement distance and elapsed time, the average drogue speed was calculated (Table 6).

Case $\mathrm{A}$ in Figure 10 shows that the longest and strongest ebb currents are curved towards the northern beach and tend to follow the shore line northward. The drogue motions appear to be influenced by significant northwards littoral drift due to wave action on the ebb tidal delta of the entrance. Moreover, cases B and $\mathrm{C}$ in Figure 10 show that the flood currents are also weak and those drogues did not move a long distance from the adjacent southern end of the beach or inside the entrance channel.

In addition, it can be seen that the average maximum current speed during flood and ebb are very similar to each other, which is a possible indication of no flood or ebb dominance. Therefore, Table 6 is in complete agreement with the results obtained from the 'Tidal Level inside the Creek' section and the 'Tidal Analysis' section.

\section{CONCLUSION}

In this study field measurements were used to investigate the 
Table 5. Tidal constituent analysis

\begin{tabular}{|c|c|c|c|c|c|c|c|c|c|c|}
\hline \multirow{2}{*}{$\begin{array}{l}\text { Major Constituents } \\
\text { Locations }\end{array}$} & \multirow{2}{*}{$\mathbf{Z O}$} & \multicolumn{2}{|c|}{ M2 } & \multicolumn{2}{|c|}{ S2 } & \multicolumn{2}{|c|}{ K1 } & \multicolumn{2}{|c|}{ O1 } & \multirow{2}{*}{ Ratio } \\
\hline & & Amp. (m) & Phase (deg) & Amp. & Phase & Amp. & Phase & Amp. & Phase & \\
\hline 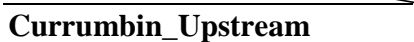 & 0.31 & 0.53 & 241 & 0.13 & 255 & 0.19 & 134 & 0.10 & 108 & 0.45 \\
\hline Currumbin_Downstream & 0.25 & 0.52 & 238 & 0.12 & 250 & 0.19 & 132 & 0.11 & 106 & 0.47 \\
\hline Palm Beach_1st & 7.32 & 0.52 & 229 & 0.14 & 231 & 0.18 & 128 & 0.11 & 104 & 0.43 \\
\hline Palm Beach_2nd & 7.77 & 0.56 & 230 & 0.12 & 245 & 0.21 & 126 & 0.11 & 104 & 0.48 \\
\hline
\end{tabular}

Table 6. Drogue characteristics

\begin{tabular}{|c|c|c|c|c|c|c|c|}
\hline & & \multicolumn{2}{|c|}{ Relocation Distance (m) } & \multicolumn{2}{|c|}{ Elapsed Time $(s)$} & \multicolumn{2}{|c|}{ Average Speed $(\mathrm{cm} / \mathrm{s})$} \\
\hline & & Drogue\# & Amount & Drogue\# & Amount & Drogue\# & Amount \\
\hline \multicolumn{8}{|c|}{ 2011/05/18 (During both Ebb and Flood) } \\
\hline \multirow{2}{*}{ Flood } & Max & 5 & 1471 & 5 & 2666 & 16 & 78 \\
\hline & Min & 16 & 117 & 16 & 151 & 10 & 26 \\
\hline \multirow{2}{*}{ Ebb } & Max & 21 & 1222 & 11 & 2718 & 3 & 73 \\
\hline & Min & 22 & 107 & 22 & 360 & 6 & 12 \\
\hline \multicolumn{8}{|c|}{ 2011/05/25 (Only during Flood) } \\
\hline \multirow{2}{*}{ Flood } & Max & 9 & 1110 & 9 & 2702 & 18 & 52 \\
\hline & Min & 20 & 58 & 11 & 454 & 20 & 5 \\
\hline \multicolumn{8}{|c|}{ 2011/05/27 (Only during Flood) } \\
\hline \multirow{2}{*}{ Flood } & Max & 11 & 1136 & 15 & 2644 & 13 & 76 \\
\hline & Min & 19 & 23 & 19 & 37 & 2 & 14 \\
\hline
\end{tabular}

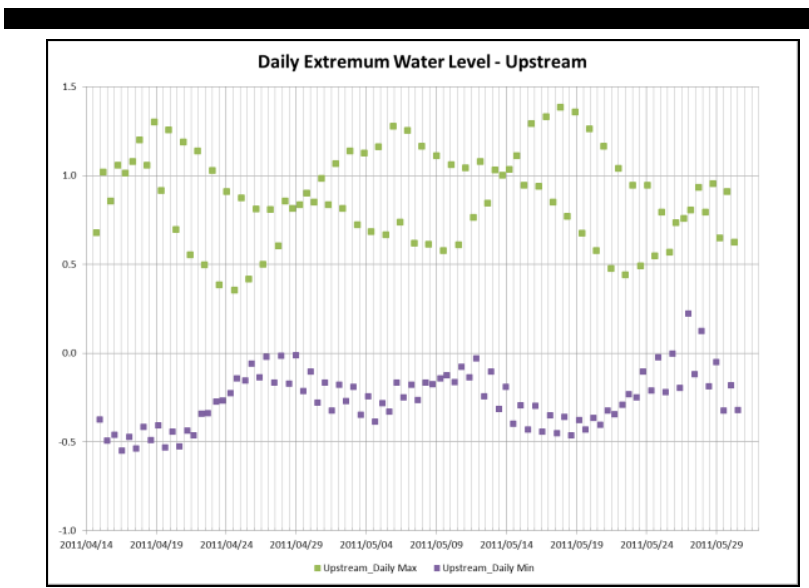

Figure 6. Daily max. and min. water levels at the upstream station

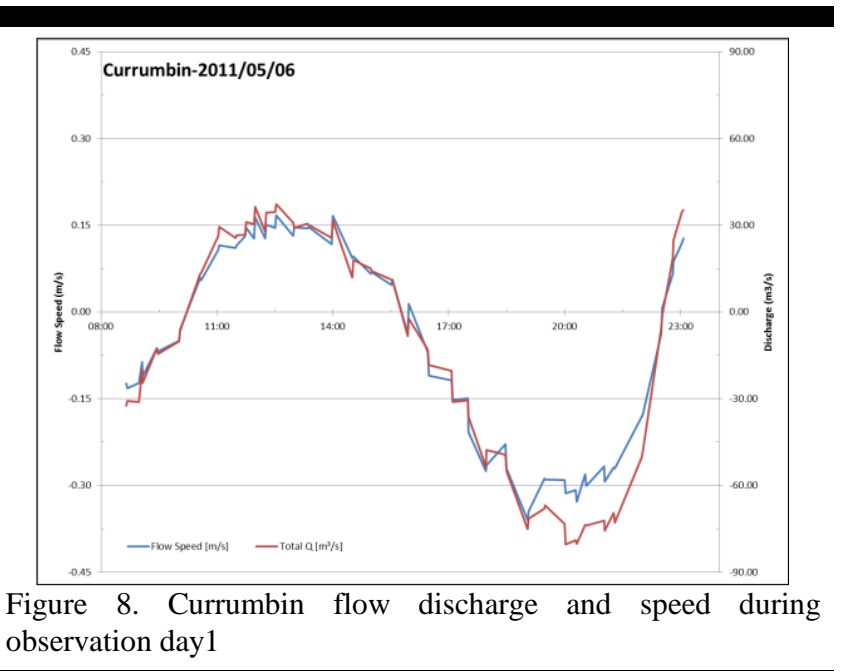

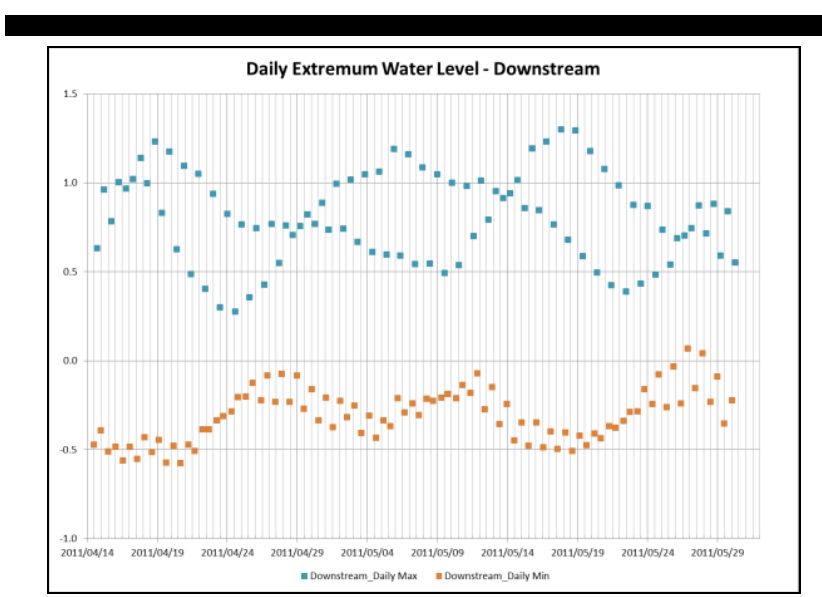

Figure 7. Daily max. and min. water levels at the downstream station

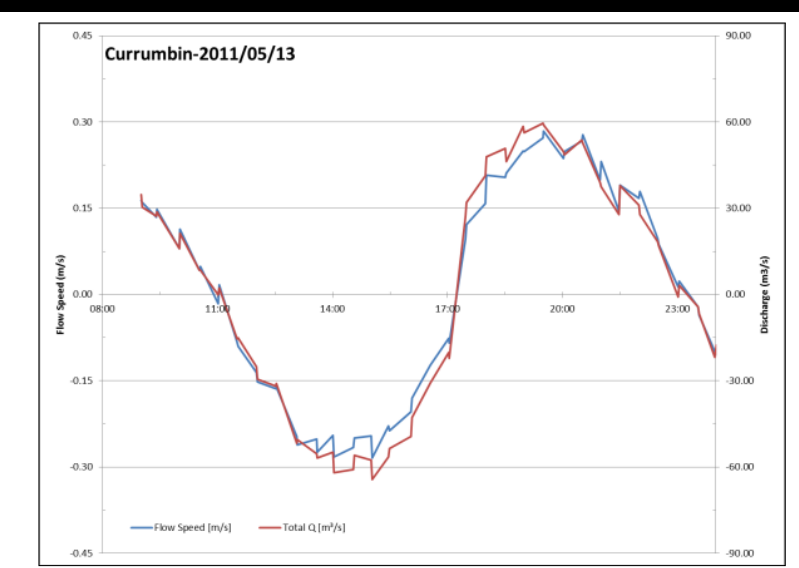

Figure 9. Currumbin flow discharge and speed during observation day 2 
dynamics of Currumbin Creek tidal entrance. The main findings are:

- Although wave stations were situated in different beach cells, they recorded the same incident wave climate in terms of direction (dominantly NE).

- Upstream station water level changes show a very similar pattern to the entrance station and indicate that the effects of the creek's geometry are marginal.

- The offshore current roses show 360 deg. distributions which reflect tidally driven events.

- The average tidal range was about $1.13 \mathrm{~m}$. Correspondingly, the average time lags were also 20 minutes. Having tidal circulation durations of about $12 \mathrm{hrs}$ and a $\left(\mathrm{K}_{1}+\mathrm{O}_{1}\right) /\left(\mathrm{M}_{2}+\mathrm{S}_{2}\right)$ ratio of less than 1.5 , suggests that the creek is a mixed, but mostly semi-diurnal tide type.

- Tidal wave propagation speeds towards upstream (flood) and towards downstream (ebb) were about $3.5 \mathrm{~m} / \mathrm{s}$ on average, indicating no clear ebb/flood dominance (but mostly symmetric tide). However, there were longer ebb-time durations which showed flood dominance. The flood dominance and asymmetric patterns are also seen from larger water discharges and velocity measurements during the flood phase.

- Tidal prism calculations show that for all cases, flood prisms are larger than ebb prisms, which suggests that the creek is flood dominated. Moreover, the absolute flood tide current speed inside the creek is larger than the ebb tide current velocity. Meanwhile the average speed of the drogues during individual flood/ebb events, are in complete agreement to the other conclusions.

\section{ACKNOWLEDGEMENT}

The work described in this publication was supported by the Griffith Centre for Coastal Management (GCCM) as part of the Gold Coast Shoreline Management Plan (GCSMP). Data was collected by DHI (Australia) and GCCM with financial support from the Gold Coast City Council (GCCC).

\section{LITERATURE CITED}

Castelle, B. O., Bourget, J., Molnar, N., Strauss, D., Deschamps, S. \& Tomlinson, R. B., 2007, 'Dynamics of a Wave-Dominated Tidal Inlet and Influence on Adjacent Beaches, Currumbin Creek, Gold Coast, Australia', Coastal Engineering, vol. 54, no. 1, pp. 77-90.

D'Agata, M. \& Mc Grath, J., 2002, 'The Use of Currumbin Creek as a Sand Reserve: Towards Better Dredging Management', paper presented to Littoral 2002: 6th International Symposium Proceedings: a multidisciplinary Symposium on Coastal Zone Research, Management and Planning, Porto, 22-26 September 2002: volume 2.

D'Agata, M. \& Tomlinson, R. B., 2001, 'Discussion of the Dredging of the Internal Delta of Currumbin Estuary and Its Impact on Adjacent Beaches', paper presented to Australasian Port and Harbour Conference (8th: 2001: Gold Coast, Qld.), Barton, A.C.T., 2001.

Hoque, M. A., Ahad, B. G. \& Saleh, E., 2010, 'Hydrodynamics and Suspended Sediment Transport at Tidal Inlets of Salut Mengkabong Lagoon, Sabah, Malaysia', International Journal Of Sediment Research, vol. 25 , no. 4 , pp. 399-410.

Hughes, S. A. (2002). "Estimating surface currents near coastal structures using dye and drogues," ERDC/CHL CHETN-VI-37, U.S. Army Engineer Research and Development Center, Vicksburg, MS, (http://chl.wes.army.mil/library/publications/chetn)

Maritime Safety Queensland, 2011, 'Currumbin Creek Bar Navigational Safety Management: A Review of Options to Manage Risks Associated with Interaction between Vessels and Surfers', Queensland Government - Department of Transport And Main Roads.

Vila-Concejo, A., Short, A. D., Hughes, M. G. \& Ranasinghe, R., 2007, 'Flood-Tide Delta Morphodynamics and Management Implications, Por Stephens, Australia', Journal of Coastal Research, no. Journal Article, pp. 705-709.

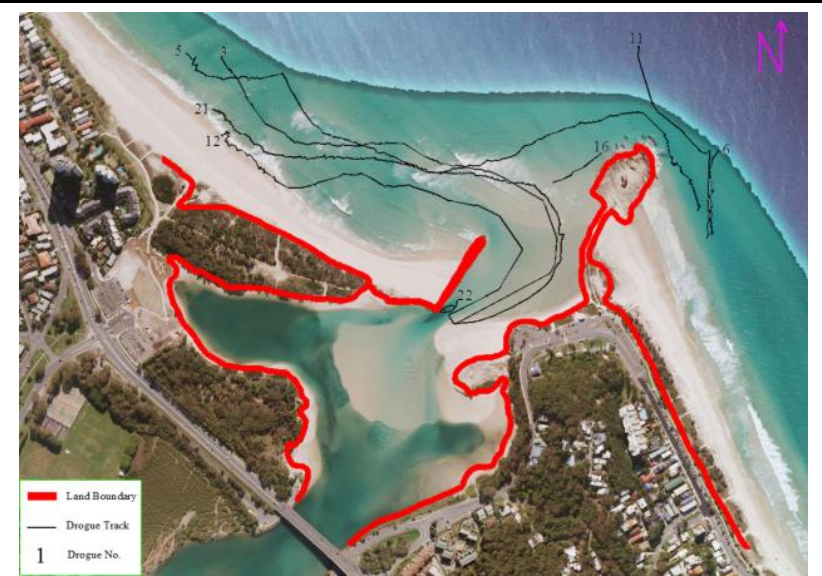

A) $2011 / 05 / 18$

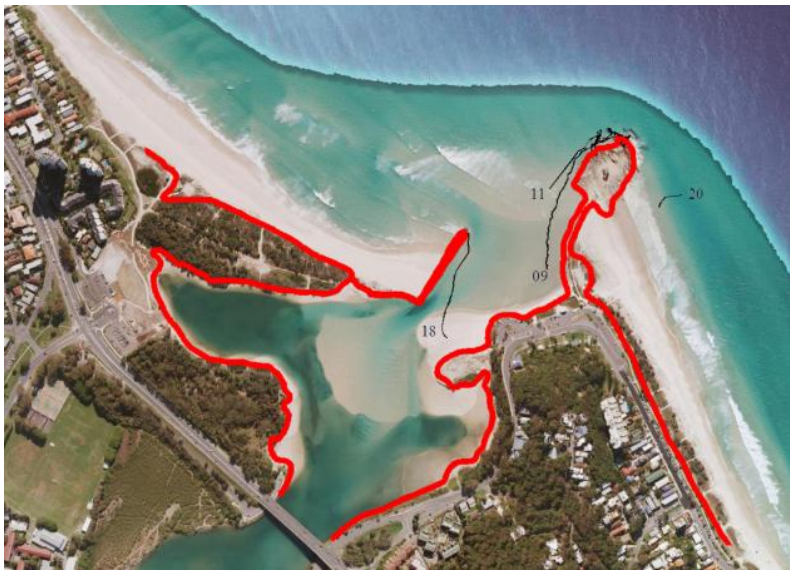

B) $2011 / 05 / 25$

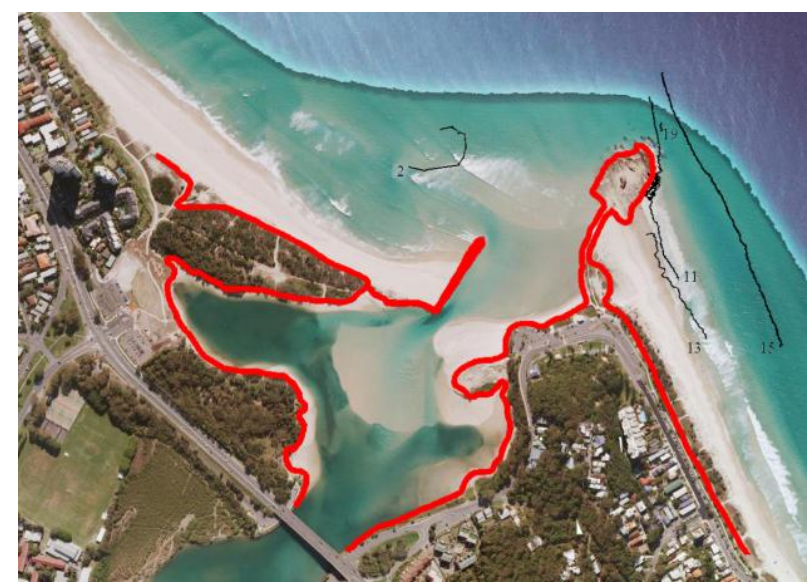

C) $2011 / 05 / 27$

Figure 10. Selected drogue tracks (based on Table 6 data) 